\title{
Organic carbon accumulation and productivity over the past 130 years in Lake Kawaguchi (central Japan) reconstructed using organic geochemical proxies
}

\author{
Shinya Yamamoto - Aurélia Hubert-Ferrari - Laura Lamair • \\ Yoshiki Miyata $\cdot$ Shinya Ochiai $\cdot$ Seiya Nagao $\cdot$ Nobuo Miyauchi $\cdot$ \\ Kunio Yoshida • Osamu Fujiwara · Yusuke Yokoyama • Vanessa M. A. Heyvaert • \\ Marc De Batist • The QuakeRecNankai Team
}

Received: 8 August 2019/Accepted: 11 July 2020/Published online: 21 July 2020

(C) Springer Nature B.V. 2020

\begin{abstract}
Organic matter in lake sediments contains information that can be used to reconstruct lake environmental histories over decades or centuries. In this study, we used organic geochemical proxies (i.e., total organic carbon [TOC], TOC/total nitrogen [TN] atomic ratios $[\mathrm{C} / \mathrm{N}]$, stable carbon isotope ratios of TOC $\left[\delta^{13} \mathrm{C}_{\mathrm{TOC}}\right]$ and palmitic acid $\left[\delta^{13} \mathrm{C}_{\mathrm{C} 16: 0}\right]$, and nitrogen isotope ratios of bulk sediment $\left[\delta^{15} \mathrm{~N}_{\text {bulk }}\right]$ ) in sediments from Lake Kawaguchi, Japan, to reconstruct detailed histories of the organic matter
\end{abstract}

Electronic supplementary material The online version of this article (https://doi.org/10.1007/s10933-020-00142-0) contains supplementary material, which is available to authorized users.

S. Yamamoto $(\bowtie)$

Mount Fuji Research Institute, Yamanashi Prefectural

Government, 5597-1 Kenmarubi, Kamiyoshida,

Fujiyoshida, Yamanashi 403-0005, Japan

e-mail: s.yamamoto@mfri.pref.yamanashi.jp

\section{A. Hubert-Ferrari · L. Lamair}

Department of Geography, University of Liège, Clos

Mercator 3, 4000 Liège, Belgium

e-mail: Aurelia.Ferrari@uliege.be

L. Lamair

e-mail: laura.lamair@ulg.ac.be

Y. Miyata $\cdot$ S. Ochiai $\cdot$ S. Nagao

Low Level Radioactivity Laboratory, Institute of Nature and Environmental Technology, Kanazawa University, O

24 Wake, Nomi, Ishikawa 923-1224, Japan

e-mail: yoshikimiyata@um.u-tokyo.ac.jp accumulation and lake productivity over the past 130 years. Vertical profiles of the mass accumulation rate (MAR) of TOC in the eastern lake basin (core KAW14-7A) showed parallel increases with the $\mathrm{C} / \mathrm{N}$ ratio from the 1960 s to the 1980 s, indicating an accelerated delivery of terrestrial organic matter via anthropogenic land-use change. In contrast, the $\mathrm{C} / \mathrm{N}$ ratios in the western and central basins (cores KAW14-1A and KAW14-4B, respectively) were almost constant prior to the 1980 s, suggesting that the increasing trends in the TOC MAR values in these cores are most likely attributable to the onset of eutrophication associated with rapid economic growth after the mid-1950s. On the other hand, the $\delta^{15} \mathrm{~N}_{\text {bulk }}$

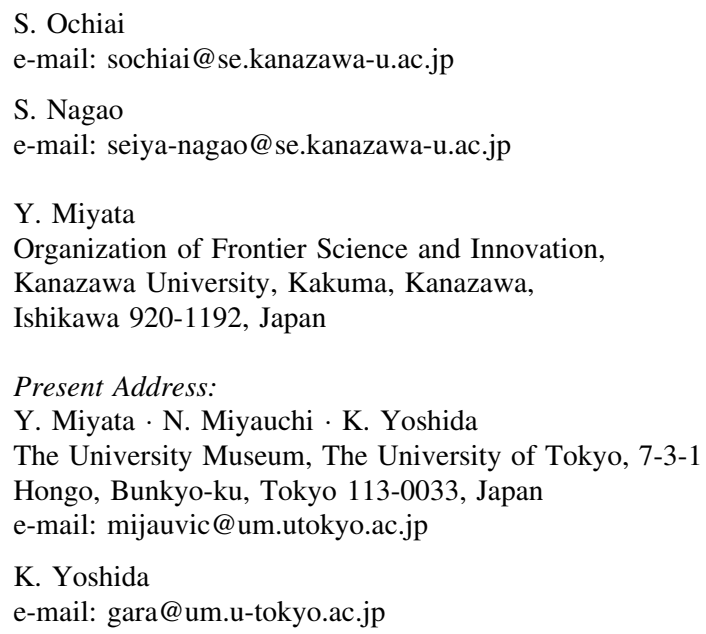


showed a gradual increase from the late 1870s, providing evidence for anthropogenic nitrogen input to the lake prior to the apparent eutrophication. After the $1960 \mathrm{~s}-1970 \mathrm{~s}$, the $\delta^{15} \mathrm{~N}_{\text {bulk }}$ values rapidly increased, demonstrating water deterioration associated with the direct nutrient discharge into the lake from domestic wastewater. The $\delta^{13} \mathrm{C}_{\mathrm{C} 16: 0}$ profiles displayed similar increasing trends to $\delta^{15} \mathrm{~N}_{\text {bulk }}$ from the mid-1960s, demonstrating a close relationship between lake productivity and anthropogenic nitrogen input in Lake Kawaguchi. Our geochemical records as a whole clearly show high algal productivity and enhanced deposition of organic matter in recent decades, suggesting that the amelioration of the lake water is a likely consequence of the transfer of nutrients to the sediment by enhanced productivity, rather than a decrease in the amount of nutrient inflow into the lake.

Keywords Lake sediment - Eutrophication · Organic matter · Carbon isotopes · Nitrogen isotopes · Aquatic biomarker

\section{Introduction}

Eutrophication is one of the most important environmental pollution problems in aquatic ecosystems (Smith et al. 1999). Eutrophication occurs naturally in lacustrine environments, (Carpenter 1981),

\section{O. Fujiwara}

Geological Survey of Japan, National Institute of

Advanced Industrial Science and Technology (AIST), 1-

1-1 Higashi, Tsukuba, Ibaraki 305-8567, Japan

e-mail: o.fujiwara@aist.go.jp

\section{Y. Yokoyama}

Atmosphere and Ocean Research Institute, The University of Tokyo, 5-1-5 Kashiwanoha, Kashiwa,

Chiba 277-8564, Japan

e-mail: yokoyama@aori.u-tokyo.ac.jp

V. M. A. Heyvaert

Geological Survey of Belgium, Royal Belgian Institute of

Natural Sciences, Brussels, Belgium

e-mail: vheyvaert@naturalsciences.be

\section{M. A. Heyvaert · M. De Batist}

Department of Geology, Faculty of Sciences, Ghent

University, Krijgslaan 281, 9000 Ghent, Belgium

e-mail: Marc.DeBatist@UGent.be however, an excessive nutrient (nitrogen [N] and phosphorus [P]) loading associated with anthropogenic activities can accelerate the rate and extent of eutrophication (i.e., cultural eutrophication), resulting in tainted drinking water sources, the degradation of recreational opportunities, and hypoxia (Carpenter et al. 1998; Chislock et al. 2013). Eutrophication can also cause changes in aquatic community structure and induce explosive algae growth, producing substances that are harmful to other organisms including livestock and humans (Carpenter et al. 1998).

Lake Kawaguchi is a volcanic-dammed lake located at the northern foot of Mount Fuji, central Japan. The lake was mesotrophic at the beginning of the twentieth century but gradually shifted to a eutrophic state by the early 1940s (Yoshimura and Kawada 1942). From the mid-1950s to the early 1970s, the lake has suffered from strong eutrophication as a result of rapid economic growth in Japan (Yamanashi Prefecture 1993). Microfossil analyses on a sediment core showed that the number of diatom frustules rapidly decreased from the 1970s, indicating a significant impact of eutrophication on the lake environment and plankton community structure (Yoshizawa and Yamamoto 2017).

A plausible cause for eutrophication in Lake Kawaguchi is the direct discharge of nutrients from domestic wastewater (Yamanashi Prefecture 1993). However, despite gradual increases in sewerage coverage in the lakeside area since 1986, chemical oxygen demand (COD), which is indicative of the dissolved organic matter concentration, has remained at the same level since the 1970s, even during the period of 2004-2013 (ten-year averages; Nakamura et al. 2016). Organic content in the surface sediments increased by up to $5.5 \%$ between 1993 and 2006 (Hirabayashi et al. 2012). Previous studies have demonstrated an accumulation of anthropogenic hydrocarbons (i.e., aliphatic and aromatic hydrocarbons) in Lake Kawaguchi sediment, associated with urbanization and development in the catchment area since the 1970s (Kobayashi et al. 2000; Ogihara et al. 2002). However, human influences on natural organic matter accumulation and lake productivity still remains unclear.

Organic geochemical properties, such as the concentration of total organic carbon (TOC), TOC to total nitrogen $(\mathrm{TN})$ ratios $(\mathrm{C} / \mathrm{N})$, and stable carbon $\left(\delta^{13} \mathrm{C}\right)$ and nitrogen $\left(\delta^{15} \mathrm{~N}\right)$ isotope ratios are commonly used 
to reconstruct lake environmental histories over time periods from decades to centuries (Meyers 2003). The accumulation rates of TOC and the $\delta^{13} \mathrm{C}$ of lake algae generally reflect aquatic productivity in lakes (Hollander and McKenzie 1991; Hollander et al. 1992; Hodell and Schelske 1998; Castañeda and Schouten 2011), whereas $\delta^{15} \mathrm{~N}$ is used to identify organic matter sources and to reconstruct past productivity rates (Herczeg et al. 2001; Talbot 2005). The $\mathrm{C} / \mathrm{N}$ ratio also provides information about the origin of the organic matter (Meyers 2003).

In this study, we examined the TOC, TN, and $\delta^{13} \mathrm{C}$ in sediment cores from Lake Kawaguchi to reconstruct temporal changes in the sources and the accumulation of TOC over the past 130 years. We also measured the $\delta^{15} \mathrm{~N}$ of bulk sediments and the $\delta^{13} \mathrm{C}$ of aquatic biomarkers in order to estimate recent changes in nitrogen sources and primary productivity.

Study site

Lake Kawaguchi $\left(35^{\circ} 31^{\prime} \mathrm{N}, 138^{\circ} 45^{\prime} \mathrm{E}\right.$; Fig. 1) is located $830.5 \mathrm{~m}$ above sea level and has a surface area of $5.7 \mathrm{~km}^{2}$ with a maximum depth of $14.6 \mathrm{~m}$. The lake basin has an east-west orientation and is divided into three sub-basins by a ridge of Neogene basement rock constituting Unoshima Island, and a ridge of subaqueous volcanic rock which is located off Fujikinohana (Yoshimura and Kawada 1944) (Fig. 1). In the eastern basin, the shoreline is developed and heavily occupied by tourism and accommodation facilities, as it is located in the vicinity of the Kawaguchiko railway station that opened in 1950. The central basin is bordered to the north by the large alluvial fan of the Okukawa and Terakawa Rivers and to the south by the lava flows of Mount Fuji, both of which are occupied by fields and houses. The large Kawaguchiko Ohashi bridge is located near the eastern end of the central basin. In the western basin, the shoreline is mostly preserved and surrounded by the Misaka and Ashiwada mountains, except for the southeastern shoreline, which is populated.

Lake Kawaguchi has no year-round, sustained river inputs except for the Terakawa and Okukawa rivers (Fig. 1). Rather, the lake is mainly fed by groundwater and seasonal surface run-off from its $103.5 \mathrm{~km}^{2}$ catchment (Horiuchi et al. 1992). Although there is no natural outlet, a small amount of water $(0.485$ $\mathrm{m}^{3} \mathrm{~s}^{-1}$ :Jan-Dec 2016 mean; unpublished data from
Yamanashi Prefecture) continuously discharges through artificial drainage tunnels for flood control, irrigation, and power generation (Fig. 1).

\section{Materials and methods}

Sampling procedure

Three short gravity cores (KAW14-1A $\left[35^{\circ} 30^{\prime} 47.89^{\prime \prime} \mathrm{N}, 138^{\circ} 45^{\prime} 5.28^{\prime \prime} \mathrm{E}\right.$, water depth $=9.65$ $\mathrm{m}], \mathrm{KAW} 14-4 \mathrm{~B} \quad\left[35^{\circ} 30^{\prime} 33.91^{\prime \prime} \mathrm{N}, 138^{\circ} 44^{\prime} 4.24^{\prime \prime} \mathrm{E}\right.$, water depth $=14.1 \mathrm{~m}] \quad$ and KAW14-7A $\left[35^{\circ} 30^{\prime} 23.85^{\prime \prime} \mathrm{N}, 138^{\circ} 46^{\prime} 10.50^{\prime \prime} \mathrm{E}\right.$, water depth $=11.1$ $\mathrm{m}]$ ) were collected from the central, western, and eastern basins, respectively, using a Uwitec gravity corer system on October 18, 2014 (Fig. 1c). The length of the cores ranged from $88.8 \mathrm{~cm}$ to $92.7 \mathrm{~cm}$, however, only the upper $20 \mathrm{~cm}$ of each core was used for this study. The cores were split, described, and sliced into 1-cm-thick subsamples for further analysis.

${ }^{210} \mathrm{~Pb},{ }^{137} \mathrm{Cs}$, and ${ }^{134} \mathrm{Cs}$ concentrations

The chronology of the KAW14-1A, KAW14-4B and KAW14-7A cores was constructed based on ${ }^{210} \mathrm{~Pb}$ (Krishnaswamy et al. 1971) and ${ }^{137}$ Cs dating (Ritchie and McHenry 1990). The powdered sediment samples were packed into a $20-\mathrm{mL}$ plastic vessel and stored for 1 month in a plastic bag to establish a radioactive equilibrium between ${ }^{222} \mathrm{Rn}$ and ${ }^{214} \mathrm{~Pb}$ (Ochiai et al. 2015). The radioactivities of ${ }^{210} \mathrm{~Pb}(46.5 \mathrm{keV}),{ }^{214} \mathrm{~Pb}$ $(352 \mathrm{keV}),{ }^{134} \mathrm{Cs}(604.7 \mathrm{keV})$ and ${ }^{137} \mathrm{Cs}(661.6 \mathrm{keV})$ were determined for every $1-\mathrm{cm}$ slice by gamma-ray spectrometry using Ge detectors at the Low Level Radioactivity Laboratory (GEM-FX5825-HJ, EG\&G ORTEC) and Ogoya underground laboratory (EGMP60-30-R, CANBERRA EURISYS; EGM3800-30-R, EURISYS MESURES), Kanazawa University (Hamajima and Komura 2004). The detectors were calibrated with reference materials JSAC0471 (Japan Society for Analytical Chemistry) and No. 42-1 (New Brunswick Laboratory [NBL]) and analytical grade $\mathrm{KCl}$. The activity of excess ${ }^{210} \mathrm{~Pb}$ $\left({ }^{210} \mathrm{~Pb}_{\mathrm{ex}}\right)$ was estimated by subtracting the ${ }^{226} \mathrm{Ra}$ activity, calculated from the activity of ${ }^{214} \mathrm{~Pb}$ (a short-lived daughter isotope of ${ }^{226} \mathrm{Ra}$ ) from the total ${ }^{210} \mathrm{~Pb}$ activity in the sediment. The sedimentation rate 


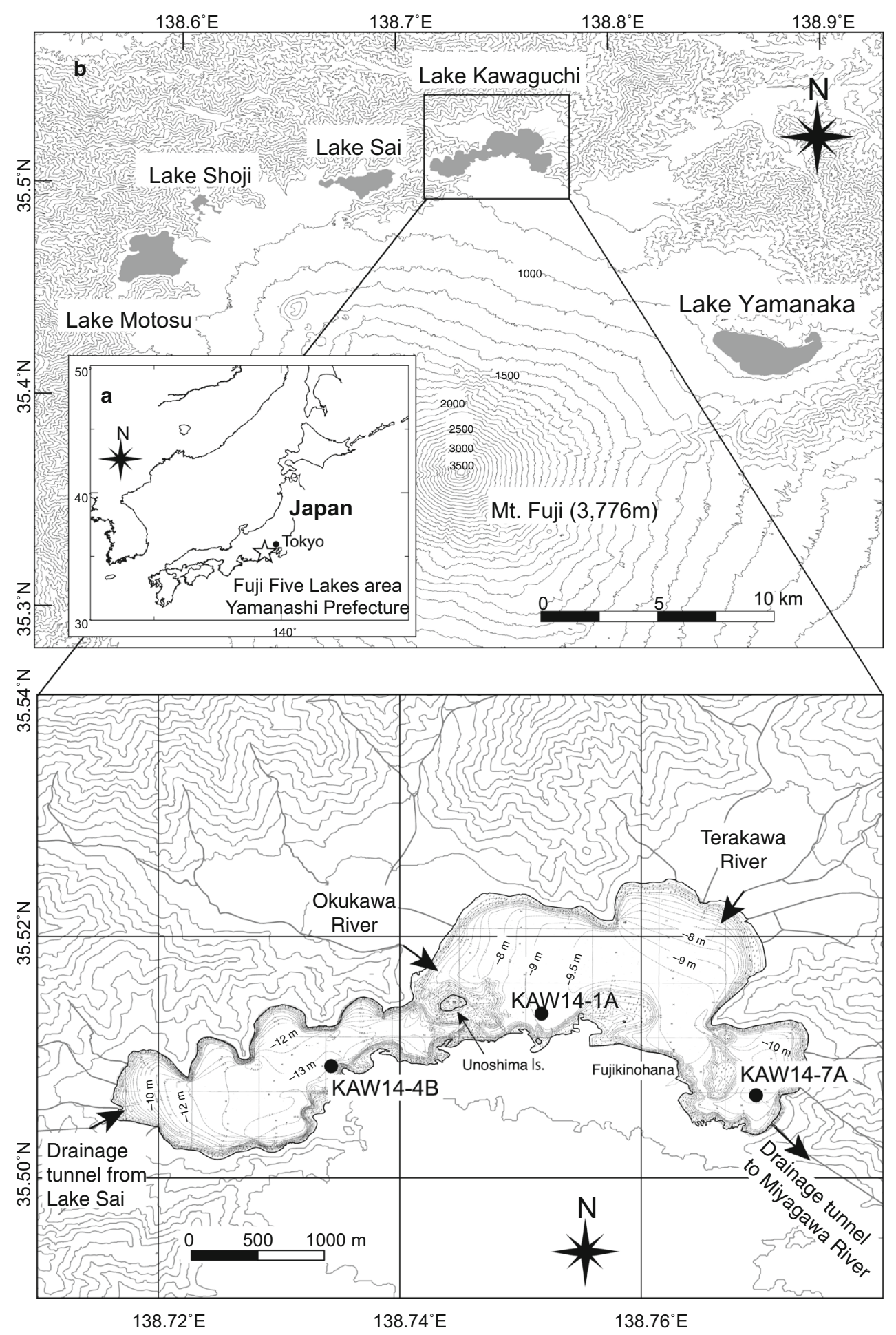

Fig. 1 Locations of a the Fuji Five Lakes area, Yamanashi Prefecture, Japan, b Lake Kawaguchi, and c a bathymetric map of Lake Kawaguchi with major inlet rivers and artificial drainage tunnels (solid arrows). Solid circles indicate sampling locations 
was calculated based on the Constant Initial Concentration (CIC) model (Robbins 1978).

TOC, TN, bulk $\delta^{13} \mathrm{C}$ and bulk $\delta^{15} \mathrm{~N}$

Prior to the bulk sediment analyses, freeze-dried sediment was treated overnight with $0.1 \mathrm{~N} \mathrm{HCl}$ to remove inorganic carbon. After acidification, sediment samples were washed repeatedly with Milli-Q water to remove acid and oven-dried at $60{ }^{\circ} \mathrm{C}$. Measurements of TOC, TN, $\delta^{13} \mathrm{C}$ and $\delta^{15} \mathrm{~N}$ were performed on the acidified samples at the University Museum of the University of Tokyo, using an elemental analyzer (EuroEA 3028-HT, EuroVector) connected to an isotope ratio mass spectrometer (Isoprime, Micromass UK Ltd). A $0.05-0.1 \mathrm{mg}$ of sample was measured for the TOC, TN, and $\delta^{13} \mathrm{C}$ analyses and $1-3 \mathrm{mg}$ for the $\delta^{15} \mathrm{~N}$ analyses. The stable isotope values are calibrated to Vienna Pee Dee Belemnite (VPDB) for $\delta^{13} \mathrm{C}$ and atmospheric $\mathrm{N}_{2}$ for $\delta^{15} \mathrm{~N}$ using international standards (IAEA-CO1, CO8, $\mathrm{CH} 7$ for $\delta^{13} \mathrm{C}$ and IAEA-N1, N2 for $\left.\delta^{15} \mathrm{~N}\right)$. The uncertainties for TOC and TN analyses were less than $\pm 0.3 \%$, and those for $\delta^{13} \mathrm{C}$ and $\delta^{15} \mathrm{~N}$ analyses were $\pm 0.1 \%$ and $\pm 0.3 \%$, respectively (Yoshida et al. 2013). The measured $\delta^{13} \mathrm{C}$ values were corrected for the variations in the $\delta^{13} \mathrm{C}$ of atmospheric $\mathrm{CO}_{2}$ from anthropogenic fossil fuel burning (the Suess effect) using the equation of Schelske and Hodell (1995).

Compound-specific $\delta^{13} \mathrm{C}$ analyses

For compound-specific $\delta^{13} \mathrm{C}$ analyses, total lipids were ultrasonically extracted from the homogenized dried sediments (0.1-2.9 g) with dichloromethane $(\mathrm{DCM}) /$ methanol $(\mathrm{MeOH})(95: 5, \mathrm{v} / \mathrm{v})$. The extracts were combined and concentrated using a rotary evaporator in a vacuum and were blown with $\mathrm{N}_{2}$ gas to near dryness. The neutral fractions of the extracts were removed with $n$-hexane/DCM (10:1) after saponification with $1.0 \mathrm{M} \mathrm{KOH}$ in $\mathrm{MeOH}$. The remaining solution was acidified with $6 \mathrm{M} \mathrm{HCl}$, and the carboxylic acids were extracted with DCM. The acidic fraction was then treated with $14 \% \mathrm{BF}_{3} / \mathrm{MeOH}$ to convert the acids into their methyl esters. Monocarboxylic acid methyl esters were obtained using column chromatography with a silica gel (deactivated with $1 \% \mathrm{H}_{2} \mathrm{O}$ ) column and elution with $n$-hexane/ $\operatorname{DCM}(1: 2)$.

The ${ }^{13} \mathrm{C} /{ }^{12} \mathrm{C}$ ratios of $n$-alkanoic acid methyl esters were determined using a HP 6890 GC instrument coupled to a Micromass IsoPrime isotope ratio mass spectrometer (GC-IRMS) via a copper oxide combustion furnace maintained at $850{ }^{\circ} \mathrm{C}$ (Yamamoto et al. 2018). The GC instrument was equipped with a HP5MS fused silica column $(30 \mathrm{~m} \times 0.32 \mathrm{~mm}$ i.d., 0.25 $\mu \mathrm{m}$ film thickness). The oven was programmed to heat from $50{ }^{\circ} \mathrm{C}$ to $120{ }^{\circ} \mathrm{C}$ at $30{ }^{\circ} \mathrm{C} \mathrm{min}{ }^{-1}$, then to $310{ }^{\circ} \mathrm{C}$ at $5{ }^{\circ} \mathrm{C} \mathrm{min}^{-1}$, and then hold isothermally for $45 \mathrm{~min}$. Sample solution $(1-2 \mu \mathrm{L})$ was injected into the GC instrument via an on-column injector with an internal standard of known isotopic composition $\left(\mathrm{C}_{26}\right.$ nalkane, $\delta^{13} \mathrm{C}=-33.1 \%$ ). The $\delta^{13} \mathrm{C}$ values are expressed as per mil (\%) relative to PDB.

To assess past productivity changes in Lake Kawaguchi, we selected palmitic acid $\left(\mathrm{C}_{16}\right.$ fatty acid $)$ as a phytoplankton biomarker. The $\mathrm{C}_{16}$ fatty acid can be abundantly produced by phytoplankton, as well as other organisms such as terrestrial plants, animals, and bacteria (Harwood 1996). However, identical radiocarbon isotope ratios $\left(\Delta^{14} \mathrm{C}\right)$ between the sedimentary $\mathrm{C}_{16}$ fatty acid and dissolved inorganic carbon (DIC) in surface water, as well as chlorophyll $a$ in the sediment, suggest that it originates from contemporary primary producers like diatoms (Yamamoto et al. 2020).

The $\delta^{13} \mathrm{C}$ values of the methyl esters were corrected for the contribution of methyl carbon $\left(\delta^{13-}\right.$ $\mathrm{C}=-43.3 \%$ ) using mass balance, and the Suess effect was corrected using the equation of Schelske and Hodell (1995). An external standard mixture containing $\mathrm{C}_{16}-\mathrm{C}_{30} n$-alkanes of known isotopic composition was injected daily into the GC-IRMS system to check the condition of the machine. An analytical error was determined from replicate measurements of the standard for the duration of the analysis and was within $\pm 0.2 \%$. Most measurements were duplicated, and the mean values are reported. 


\section{Results}

\section{Core lithology}

The upper $20 \mathrm{~cm}$ of sediment cores consisted of brown-gray to olive-gray massive clay with occasional intercalation of plant remains, with the exception of the 11.4-15-cm depth interval of the KAW14-1A core, in which the sediment was characterized by an organic-rich black clay layer.

\section{Core chronology}

Vertical distributions of ${ }^{210} \mathrm{~Pb}_{\mathrm{ex}},{ }^{137} \mathrm{Cs}$, and ${ }^{134} \mathrm{Cs}$ activity concentrations in sediment cores from Lake Kawaguchi as a function of mass depth are shown in Fig. 2. In general, ${ }^{210} \mathrm{~Pb}$ is a natural radioactive isotope with a half-life of 22.26 years, whereas ${ }^{137} \mathrm{Cs}$ is a fission product introduced into the atmosphere as a result of atmospheric nuclear weapons tests conducted in the early 1950s-1960s. The emission of radiocesium is also known in Japan from the Fukushima
Daiichi nuclear disaster after the 2011 Tohoku earthquake and tsunami and its ${ }^{134} \mathrm{Cs} /{ }^{137} \mathrm{Cs}$ ratio is characterized as unity (Buesseler et al. 2011; Honda et al. 2012).

\section{KAW14-1A}

The ${ }^{210} \mathrm{~Pb}_{\text {ex }}$ profile for the KAW14-1A core showed a step-like decrease from $0.249 \pm 0.052 \mathrm{~Bq} \mathrm{~g}^{-1}$ at the surface to $0.017 \pm 0.007 \mathrm{~Bq} \mathrm{~g}^{-1}$ at a $19-20 \mathrm{~cm}$ depth (mass depth $=6.895 \mathrm{~g} \mathrm{~cm}^{-2}$; Fig. 2a). The ${ }^{210} \mathrm{~Pb}_{\mathrm{ex}}$ concentrations were almost constant within the upper $6 \mathrm{~cm}$ (mass depth $=0.171-1.822 \mathrm{~g} \mathrm{~cm}^{-2}$ ), indicating mixing of the surface layer. The ${ }^{137} \mathrm{Cs}$ profile showed two maxima at depths of $2-3 \mathrm{~cm}$ $\left(0.043 \pm 0.001 \mathrm{~Bq} \mathrm{~g}^{-1}\right.$; mass depth $\left.=0.807 \mathrm{~g} \mathrm{~cm}^{-2}\right)$ and $\quad 13-14 \mathrm{~cm} \quad\left(0.028 \pm 0.001 \mathrm{~Bq} \mathrm{~g}^{-1} ; \quad\right.$ mass depth $=4.837 \mathrm{~g} \mathrm{~cm}^{-2}$ ) (Fig. 2). These peaks can be correlated with the 2011 Fukushima nuclear disaster and the fallout peak of ${ }^{137} \mathrm{Cs}$ in 1963 , respectively. The ${ }^{210} \mathrm{~Pb}$ chronology also supported this estimation. The ${ }^{134} \mathrm{Cs} /{ }^{137} \mathrm{Cs}$ activity ratios corrected for radioactive
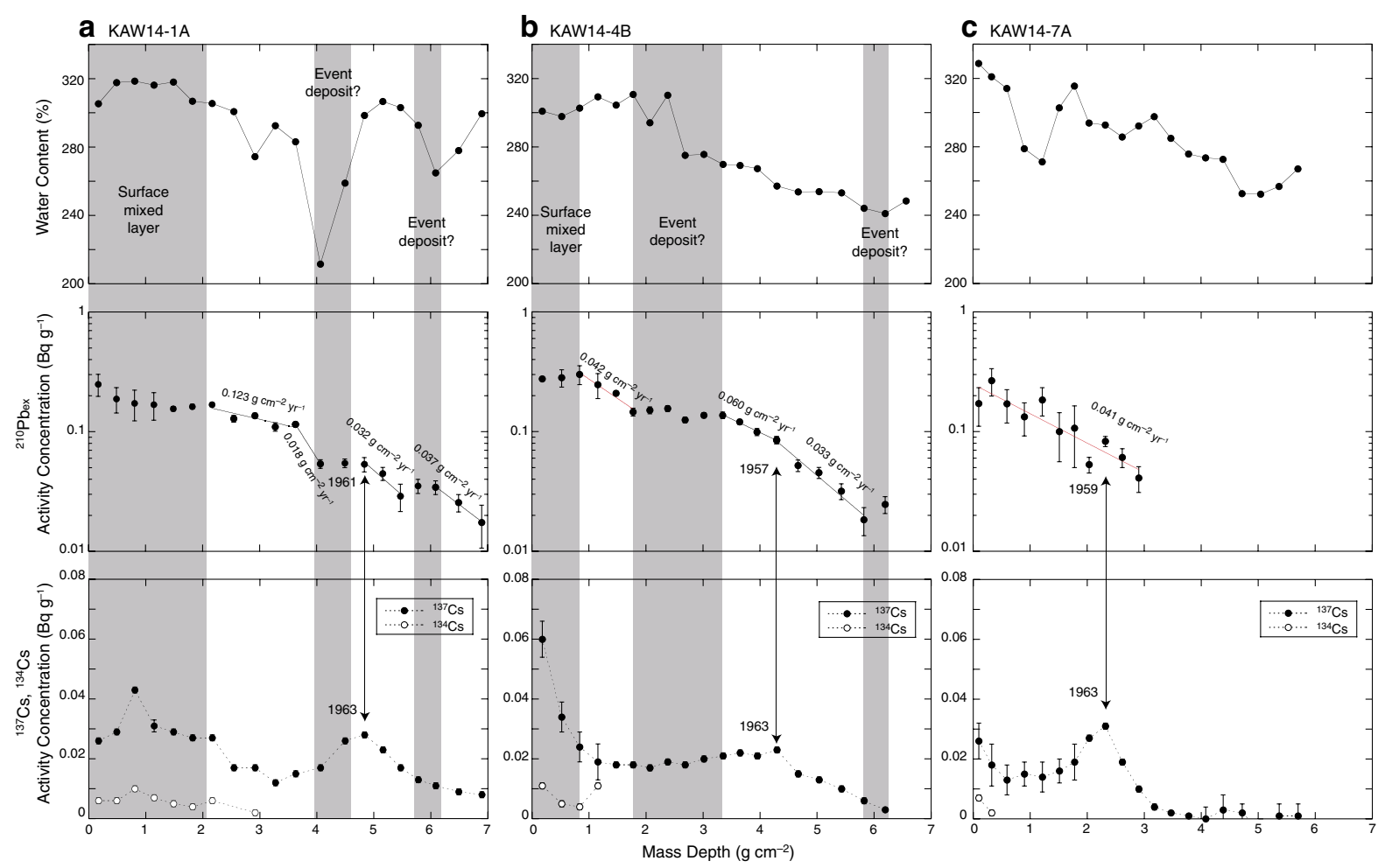

Fig. 2 Vertical distributions of the activity concentrations of ${ }^{210} \mathrm{~Pb}_{\mathrm{ex}},{ }^{137} \mathrm{Cs}$, and ${ }^{134} \mathrm{Cs}$ in a KAW14-1A, b KAW $14-4 \mathrm{~B}$, and c KAW14-7A cores from Lake Kawaguchi, Japan, as a function of mass depth. Gray bars indicate intervals where a disturbance was observed in the ${ }^{210} \mathrm{~Pb}_{\text {ex }}$ profiles 
decay after the Fukushima Daiichi disaster $\left({ }^{134} \mathrm{Cs} /{ }^{137-}\right.$ $\left.\mathrm{Cs}_{20110311}\right)$ ranged between $0.59 \pm 0.08$ to $0.72 \pm 0.10$ for the upper $4 \mathrm{~cm}$ (mass depth $=\sim 1.146 \mathrm{~g} \mathrm{~cm}^{-2}$ ) of the core (Fig. 2), supporting evidence of the ${ }^{137} \mathrm{Cs}$ contribution from the Fukushima nuclear power plants $\left({ }^{134} \mathrm{Cs} /{ }^{137} \mathrm{Cs} \approx 1\right.$; Buesseler et al. 2011; Honda et al. 2012).

\section{KAW14-4B}

The ${ }^{210} \mathrm{~Pb}_{\text {ex }}$ profile for the KAW14-4B core showed a step-like decrease from $0.280 \pm 0.055 \mathrm{~Bq} \mathrm{~g}^{-1}$ at a $2-3 \mathrm{~cm}$ depth (mass depth $=0.837 \mathrm{~g} \mathrm{~cm}^{-2}$ ) to $0.019 \pm 0.005 \mathrm{~Bq} \mathrm{~g}^{-1}$ at a $17-18 \mathrm{~cm}$ depth (mass depth $=5.826 \mathrm{~g} \mathrm{~cm}^{-2}$ ) (Fig. 2). The ${ }^{210} \mathrm{~Pb}_{\mathrm{ex}}$ concentrations were almost constant within the upper $3 \mathrm{~cm}$, suggesting mixing of the surface layer. The ${ }^{137} \mathrm{Cs}$ profile at this site also showed two maxima, at the surface $\left(0.060 \pm 0.006 \mathrm{~Bq} \mathrm{~g}^{-1}\right)$ and at a $13-14 \mathrm{~cm}$ depth $\quad\left(0.023 \pm 0.001 \mathrm{~Bq} \mathrm{~g}^{-1} ; \quad\right.$ mass depth $=4.296 \mathrm{~g} \mathrm{~cm}^{-2}$ ), corresponding to the 2011 Fukushima nuclear disaster and the fallout peak of ${ }^{137} \mathrm{Cs}$ in 1963 , respectively. The ${ }^{134} \mathrm{Cs} /{ }^{137} \mathrm{Cs}_{20110311}$ ratio ranged from $0.49 \pm 0.11$ to $0.77 \pm 0.09$ for the upper $4 \mathrm{~cm}$ (mass depth $=\sim 1.156 \mathrm{~g} \mathrm{~cm}^{-2}$ ) of the core.

\section{KAW14-7A}

The ${ }^{210} \mathrm{~Pb}_{\text {ex }}$ profile for the KAW14-7A core showed a linear decreasing trend from $0.172 \pm 0.061 \mathrm{~Bq} \mathrm{~g}^{-1}$ at the surface to $0.041 \pm 0.010 \mathrm{~Bq} \mathrm{~g}^{-1}$ at a $10-11 \mathrm{~cm}$ depth (mass depth $=2.905 \mathrm{~g} \mathrm{~cm}^{-2}$; Fig. 2), which yielded a sedimentation rate of $0.14 \mathrm{~cm} \mathrm{yr}^{-1}$. Although the ${ }^{210} \mathrm{~Pb}_{\mathrm{ex}}$ concentrations were below the detection limit at a $12-20 \mathrm{~cm}$ depth, the age of sediments below this depth was extrapolated using the sedimentation rate of $0.14 \mathrm{~cm} \mathrm{yr}^{-1}$ (Fig. 3) as vertical profiles of ${ }^{210} \mathrm{~Pb}_{\mathrm{ex}}$ in a core collected near this site revealed a linear sedimentation rate for the upper $20 \mathrm{~cm}$ layer (Sakaguchi et al. 2004). The ${ }^{137} \mathrm{Cs}$ profile at this site also showed two maxima, at the surface $\left(0.026 \pm 0.006 \mathrm{~Bq} \mathrm{~g}^{-1}\right)$ and at a $8-9 \mathrm{~cm}$ depth $\left(0.027 \pm 0.004 \mathrm{~Bq} \mathrm{~g}^{-1}\right.$; mass depth $\left.=2.320 \mathrm{~g} \mathrm{~cm}^{-2}\right)$ and the ${ }^{134} \mathrm{Cs} /{ }^{137} \mathrm{Cs}_{20110311}$ ratio ranged from $0.55 \pm 0.21$ to $0.79 \pm 0.15$ within the upper $2 \mathrm{~cm}$ (mass depth $=\sim 0.324 \mathrm{~g} \mathrm{~cm}^{-2}$ ) of the core.

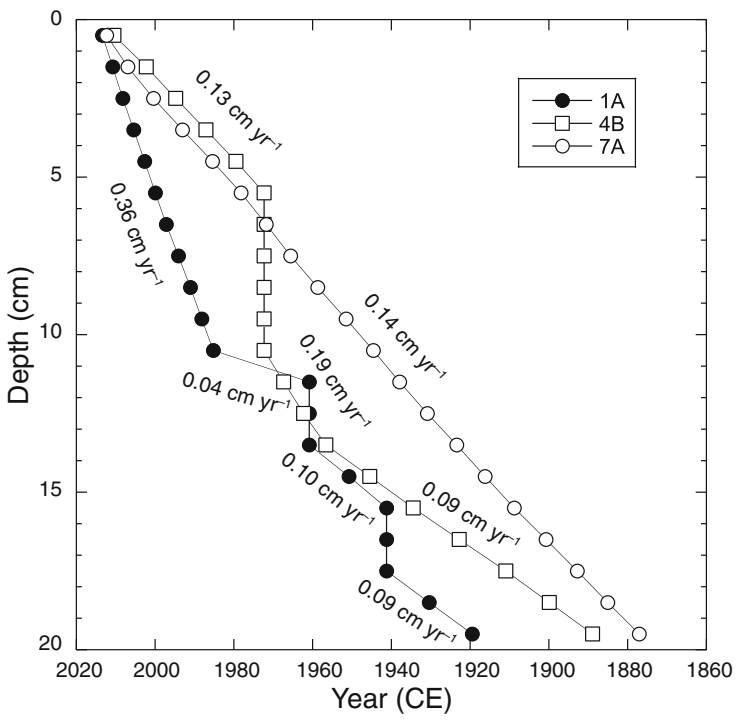

Fig. 3 Age-depth model of the KAW14-1A, KAW14-4B, and KAW14-7A cores based on ${ }^{210} \mathrm{~Pb}$ and ${ }^{137} \mathrm{Cs}$ dating

TOC, $\mathrm{C} / \mathrm{N}$ ratios, and $\delta^{13} \mathrm{C}$ and $\delta^{15} \mathrm{~N}$

The mass accumulation rate (MAR) of TOC ranged from $1.362-6.659 \mathrm{mg} \mathrm{cm}^{-2} \mathrm{yr}^{-1}$ in KAW14-1A, $1.071-2.125 \mathrm{mg} \mathrm{cm}^{-2} \mathrm{yr}^{-1}$ in KAW14-4B, and $1.463-2.293 \mathrm{mg} \mathrm{cm}^{-2} \mathrm{yr}^{-1}$ in KAW14-7A (Fig. 4). In contrast, the $\mathrm{C} / \mathrm{N}$ atomic ratios ranged from 9.9-11.4 in KAW14-1A, 8.5-9.6 in KAW14-4B, and 9.5-10.8 in KAW14-7A (Fig. 4). The Suess-corrected $\delta^{13} \mathrm{C}$ of TOC $\left(\delta^{13} \mathrm{C}_{\mathrm{TOC}}\right)$ showed large offsets among the cores, in which KAW14-1A had the highest $\delta^{13} \mathrm{C}_{\mathrm{TOC}}$ values, ranging from -25.5 to $-24.7 \%$, followed by cores KAW14-7A and KAW14-4B, for which the $\delta^{13} \mathrm{C}_{\mathrm{TOC}}$ values ranged from -26.9 to $25.2 \%$ and -27.4 to $-26.4 \%$, respectively (Fig. 4). The $\delta^{15} \mathrm{~N}_{\text {bulk values ranged from } 4.5-5.7 \% \text { o }}$ in KAW14-1A, 4.1-5.5\% in KAW14-4B, and $3.8-5.3 \%$ in KAW14-7A, and the Suess-corrected $\delta^{13} \mathrm{C}_{\mathrm{C} 16: 0}$ ranged from -31.9 to $-29.8 \%$ in KAW14-1A, -32.4 to $-30.2 \%$ in KAW14-4B, and -32.3 to $-28.3 \%$ in KAW14-7A (Fig. 5).

\section{Discussion}

Spatiotemporal changes in sedimentation rate

Age-depth models for the Lake Kawaguchi cores revealed relatively constant sedimentation rates in 
Fig. 4 Temporal changes in a mass accumulation rates (MAR) of total organic carbon (TOC), b TOC to total nitrogen $(\mathrm{TN})$ atomic ratios $(\mathrm{C} / \mathrm{N})$, and $\mathbf{c}$ the Suess-corrected $\delta^{13} \mathrm{C}$ of TOC $\left(\delta^{13} \mathrm{C}_{\mathrm{TOC}}\right)$ over the past 130 years in Lake Kawaguchi, Japan

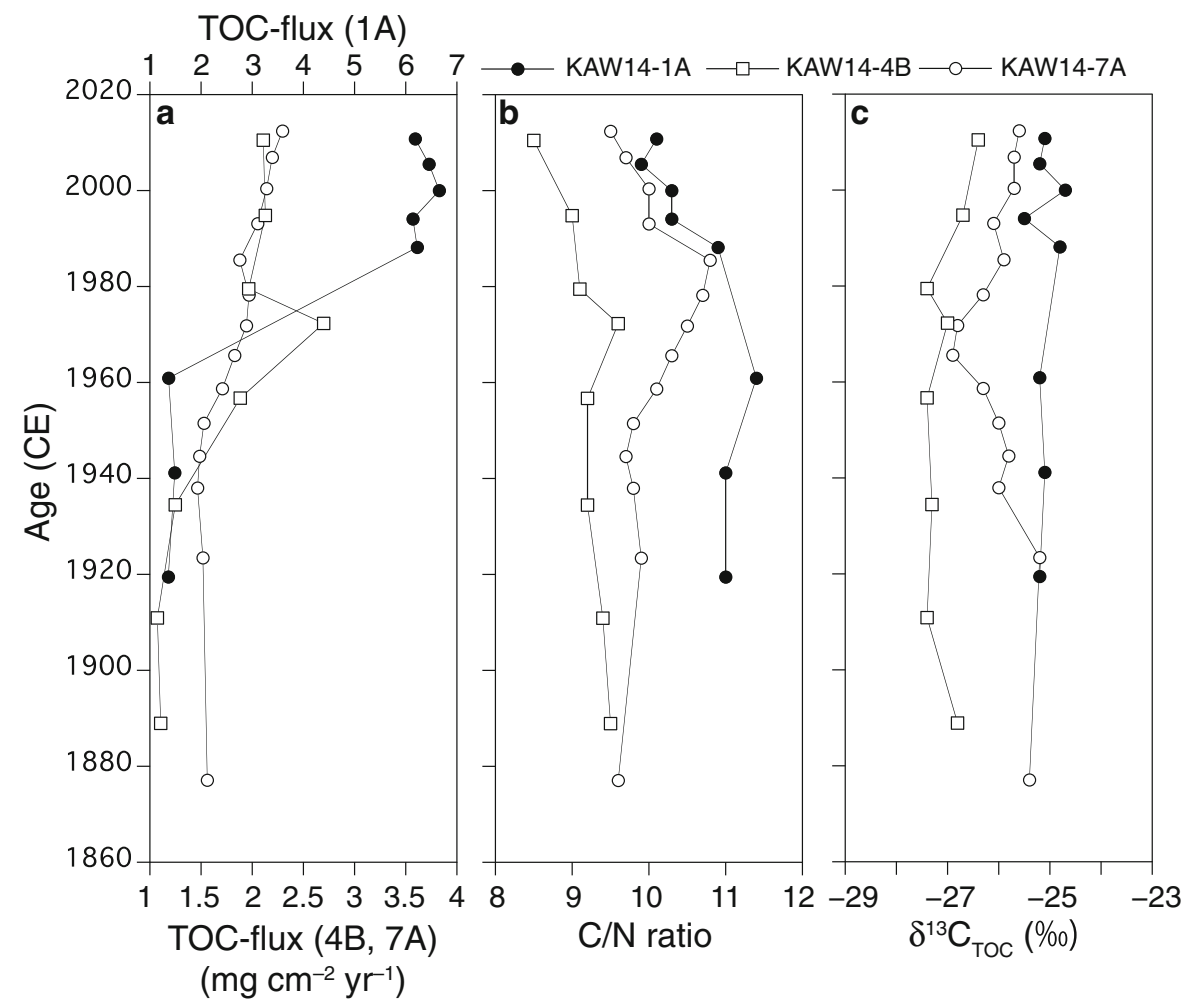

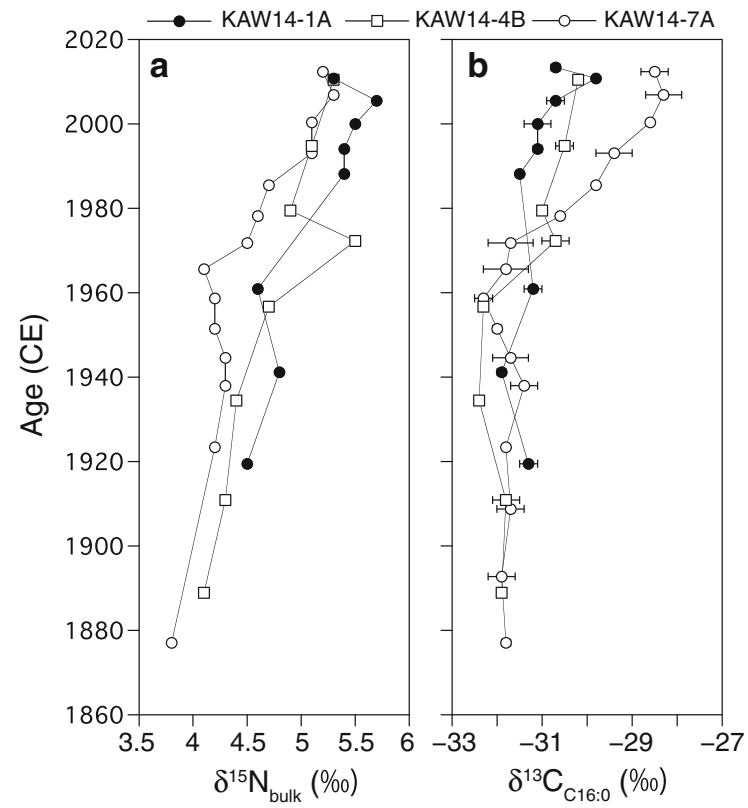

Fig. 5 Temporal changes in a the stable nitrogen isotope ratios of bulk sediment $\left(\delta^{15} \mathrm{~N}_{\text {bulk }}\right)$ and $\mathbf{b}$ the Suess-corrected $\delta^{13} \mathrm{C}$ of the palmitic acid $\delta^{13} \mathrm{C}_{\mathrm{C} 16: 0}$ ) values over the past 130 years in Lake Kawaguchi, Japan core KAW14-7A and in cores KAW14-1A and KAW14-4B prior to the 1960s (Fig. 3). In contrast, the sedimentation rate in core KAW14-4B doubled from 0.09 to $0.19 \mathrm{~cm} \mathrm{yr}^{-1}$ after the late 1950s (Fig. 3), suggesting an influence of eutrophication in the western basin since the mid-1950s (Yamanashi-Prefecture 1993). The sedimentation rate in core KAW14$1 \mathrm{~A}$ also showed a significant increase in the upper $10 \mathrm{~cm} \mathrm{(} 0.36 \mathrm{~cm} \mathrm{yr}^{-1}$; Fig. 3), which may be related to changes in lake productivity and eutrophication.

We observed constant ${ }^{210} \mathrm{~Pb}_{\mathrm{ex}}$ concentrations at depths of $11-14 \mathrm{~cm}$ (mass depth $=4.966-4.837$ $\mathrm{g} \mathrm{cm}^{-2}$ ) and 16-18 $\mathrm{cm}$ (mass depth $=5.779-6.086$ $\mathrm{g} \mathrm{cm}^{-2}$ ) in core KAW14-1A. Within these two layers, water content showed significant decreases (Fig. 2a), suggesting instantaneous depositional events of sediments with different grain size distribution. These events correspond to the years 1941 and 1960, and may be related to the unusually high lake level in 1938 and a series of typhoons (including "the Isewan Typhoon") in 1960 , respectively. The ${ }^{210} \mathrm{~Pb}_{\text {ex }}$ profile for core KAW14$4 \mathrm{~B}$ also showed disturbances at depths between 5 and $11 \mathrm{~cm}$ (mass depth $=1.773-3.352 \mathrm{~g} \mathrm{~cm}^{-2}$ ) and 
$17-19 \mathrm{~cm}$ (mass depth $=5.826-6.195 \mathrm{~g} \mathrm{~cm}^{-2}$ ), suggesting the occurrence of instantaneous depositional events in 1972 and 1929, respectively.

Temporal changes in the accumulation rate and the origin of organic matter in lake sediment

Figure 4 shows temporal changes in the MARs of TOC, $\mathrm{C} / \mathrm{N}$ ratios, and the $\delta^{13} \mathrm{C}_{\mathrm{TOC}}$ over the past 130 years. The MAR of TOC in the KAW14-4B core maintained a relatively constant value between 1.071 and $1.246 \mathrm{mg} \mathrm{cm}^{-2} \mathrm{yr}^{-1}\left(1.140 \pm 0.093 \mathrm{mg} \mathrm{cm}^{-2}\right.$ $\mathrm{yr}^{-1}$ on average) until 1934 (Fig. 4a) and then gradually increased from the mid-1950s to 2014, with a maximum value of $2.696 \mathrm{mg} \mathrm{cm}^{-2} \mathrm{yr}^{-1}$ in 1972 (Fig. 4a). Similarly, the MAR of TOC in the KAW147A core showed an almost constant value $\left(1.510 \pm 0.037 \mathrm{mg} \mathrm{cm}^{-2} \mathrm{yr}^{-1}\right.$ on average $)$ until approximately 1951 , followed by a gradual increase of $\sim 2.293 \mathrm{mg} \mathrm{cm}^{-2} \mathrm{yr}^{-1}$ until 2014 (Fig. 4a). The MAR of TOC in the KAW14-1A core displayed a relatively constant value $\left(1.406 \pm 0.070 \mathrm{mg} \mathrm{cm}^{-2}\right.$ $\mathrm{yr}^{-1}$ on average) until 1960, and showed an abrupt increase to $\sim 6.334 \mathrm{mg} \mathrm{cm}^{-2} \mathrm{yr}^{-1}$ by the late $1980 \mathrm{~s}$ (Fig. 4a).

In general, the MARs of TOC track changes in the delivery rates of organic matter to lake sediments (Meyers and Lallier-Vergès 1999). However, it is important to note that the lake sediments contained TOC from various sources and are affected by postdepositional degradation (Meyers 2003). Vertical profiles of the $\mathrm{C} / \mathrm{N}$ ratio show increases from the late 1950s to the mid-1980s in core KAW14-7A (eastern basin; Fig. 4b), suggesting an enhanced input of landplant material in addition to algal organic matter. This interpretation is based on the rationale that the $\mathrm{C} / \mathrm{N}$ ratio of lake algae generally ranges between 4 and 10 , while terrestrial higher plants usually have $\mathrm{C} / \mathrm{N}$ ratios of > 20 (Meyers 1994).

In Lake Kawaguchi, the southern lakeside was reclaimed between 1964 and 1967 in the eastern basin, and the Kawaguchiko Ohashi bridge was constructed between 1968 and 1971 near the western edge of the eastern basin. Parallel increases in the TOC MAR and $\mathrm{C} / \mathrm{N}$ ratio during these periods therefore likely represent an accelerated delivery of terrestrial organic matter to the lake associated with anthropogenic landuse changes. The lack of clear increasing trends in the cores from the western and central basins can be consistently explained by the distal locations of these cores from the construction sites.

In addition, post-depositional degradation possibly affected the TOC MAR profiles. The $\mathrm{C} / \mathrm{N}$ ratios showed decreases in the upper $5 \mathrm{~cm}$ (KAW14-4B and KAW14-7A) to $10 \mathrm{~cm}$ (KAW14-1A) of the cores (Fig. 4b), implying a minor degradation of labile, nitrogen-rich aquatic compounds (Meyers and Ishiwatari 1993). In contrast, the $\mathrm{C} / \mathrm{N}$ ratios were almost constant until the 1980s in core KAW14-4B and until the late 1980s in core KAW14-1A, except for slight increases in 1972 and 1960, respectively. These results suggest that the rapid increases in the TOC MAR values in these cores are attributable to the onset of eutrophication associated with rapid economic growth from the mid-1950s (Yamanashi-Prefecture 1993).

To date, only a limited number of studies have compared more than one core from a single lake (Wang et al. 2009; Lu et al. 2014; Sarkar et al. 2014; Kumar et al. 2016). However, these studies strongly suggested that a single core is insufficient to represent a whole lake environment due to the spatial variability of sediment distribution. Our records also show significant disparity among cores, which highlights the importance of using multiple sediment cores for reliable reconstruction of lacustrine environmental changes. Moreover, comparisons of the core records with the documented histories of changes around the lake are significantly useful to improve interpretation of sub-basin scale changes in sediment characteristics.

Temporal changes in the $\delta^{13} \mathrm{C}_{\mathrm{TOC}}$ in lake sediment

$\delta^{13} \mathrm{C}_{\mathrm{TOC}}$ is widely used as a proxy for aquatic productivity in lakes (Hollander and McKenzie 1991) even though the values are susceptible to variation in the anaerobic respiration of organic matter (Hollander and Smith 2001) and the source of organic matter (Castañeda et al. 2011). Vertical profiles of the $\delta^{13} \mathrm{C}_{\mathrm{TOC}}$ show no corresponding trends with the $\mathrm{C} / \mathrm{N}$ ratios or TOC MAR values (Fig. 4c), suggesting that the values were not solely influenced by the source of organic matter and productivity within the lake. Nevertheless, we cannot fully rule out the possibility that the Suess effect may be overestimated for the $\delta^{13} \mathrm{C}_{\mathrm{TOC}}$ since Yamamoto et al. (2020) have recently reported a ${ }^{14} \mathrm{C}$ age of $937 \pm 22 \mathrm{yr} \mathrm{BP}$ from the lake DIC in Lake Kawaguchi, suggesting potential 
influence of exogenous old carbon sources and groundwater.

On the other hand, the $\delta^{13} \mathrm{C}_{\mathrm{TOC}}$ profiles showed large differences between the cores, with the highest averaged $\delta^{13} \mathrm{C}_{\mathrm{TOC}}$ values in KAW14-1A $(-26.3 \pm 0.8 \%$ ) , followed by KAW14-7A $(-26.9$ $\pm 0.7 \%$ ) , and KAW14-4B $(-27.9 \pm 0.5 \%$ o $)$ cores. In lacustrine sediments, the $\delta^{13} \mathrm{C}$ of organic matter produced by $\mathrm{C}_{4}$ plants is known to show distinct values from those produced by $\mathrm{C}_{3}$ plants and phytoplankton (Meyers 2003). Because there are many corn $\left(C_{4}\right.$ plant) fields in the watershed of Lake Kawaguchi where land is covered by water-permeable volcaniclastics of Mount Fuji, these offsets can be attributed to terrestrial organic matter contributions, including $\mathrm{C}_{4}$ materials, in addition to changes in aquatic productivity. In support of this, the highest $\mathrm{C} / \mathrm{N}$ ratios were observed in core KAW14-1A $(10.6 \pm 0.6)$, followed by cores KAW14-7A $(10.0 \pm 0.4)$ and KAW14-4B $(9.2 \pm 0.3)$. The highest values in the central basin (KAW14-1A) may be related to the heavy loading of terrigenous materials from the northern Misaka mountain, while such materials may be less significant in the other cores due to rather limited fluvial inputs. Alternatively, distance from a shore could also account for the $\delta^{13} \mathrm{C}_{\mathrm{TOC}}$ offsets among the cores through the changes in littoral influence (Mayr et al. 2005).

Temporal changes in nitrogen sources and productivity

$\delta^{15} \mathrm{~N}_{\text {bulk }}$ is generally used to identify sources of organic matter and to reconstruct past productivity rates (Herczeg et al. 2001; Talbot 2005). The $\delta^{15} \mathrm{~N}_{\text {bulk }}$ values exhibited gradual increases from $3.8 \%$ in the late 1870 s to $5.3 \%$ most recently (Fig. 5a). However, none of these profiles track changes in the $\mathrm{C} / \mathrm{N}$ ratios, indicating that the source of organic matter was not an important factor affecting the $\delta^{15} \mathrm{~N}_{\text {bulk }}$ of Lake Kawaguchi sediment. Dissolved oxygen profiles in the lake water since 1917 demonstrated that the anoxic bottom-water conditions did not occur until the summer of 1941 (Yoshimura and Kawada 1942). Hence, denitrification is unlikely to have caused the $\delta^{15} \mathrm{~N}_{\text {bulk }}$ increases prior to the 1930s. As the $\delta^{15} \mathrm{~N}$ values of anthropogenic nitrates $\left(\mathrm{NO}_{3}{ }^{-}\right)$, such as farm runoff and human sewage, are significantly higher than those from the forest (Teranes and Bernasconi
2000; Leavitt et al. 2006; Umezawa et al. 2009), the $\delta^{15} \mathrm{~N}_{\text {bulk }}$ increase, though it is close to the analytical error of $0.3 \%$, provides evidence for anthropogenic nitrogen input to the lake long before the apparent eutrophication. In contrast, the $\delta^{15} \mathrm{~N}_{\text {bulk }}$ values rapidly increased after the 1960s-1970s, especially in cores KAW14-1A and KAW14-7A. Such increases in the $\delta^{15} \mathrm{~N}_{\text {bulk }}$ likely correspond to water deterioration associated with the direct discharge of nutrients from domestic wastewater (Yamanashi Prefecture 1993) which were further aggravated by increased denitrification under expanded bottom water anoxia with high productivity. The $\delta^{15} \mathrm{~N}_{\text {bulk }}$ values were almost constant after the 1990s in KAW14-7A (Fig. 5a), highlighting the effects of the construction of a sewage system in the lakeside area in 1986.

In addition to TOC MAR and $\delta^{15} \mathrm{~N}_{\text {bulk }}$, the $\delta^{13} \mathrm{C}$ of phytoplankton is a widely used proxy for aquatic productivity in lakes; higher $\delta^{13} \mathrm{C}$ values generally indicate increased productivity (Hollander and McKenzie 1991). The Suess-corrected $\delta^{13} \mathrm{C}_{\mathrm{C} 16: 0}$ values were almost constant at around - 32\% from 1880 to $~ 1960$ in cores KAW14-4B and KAW14$7 \mathrm{~A}$, followed by a trend toward more ${ }^{13} \mathrm{C}$-enriched values after the $1960 \mathrm{~s}$, by up to $\sim 2.1 \%$ and $\sim$ $4.0 \%$, respectively (Fig. 5b). As mentioned above, the Suess effect could be overestimated due to the input of DIC from exogenous carbon sources and groundwater, however, the original (uncorrected) $\delta^{13} \mathrm{C}_{\mathrm{C} 16: 0}$ profiles in these cores also show apparent increases after the 1960s (ESM1). Accordingly, contemporaneous increases in $\delta^{13} \mathrm{C}_{\mathrm{C} 16: 0}$ and $\delta^{15} \mathrm{~N}_{\text {bulk }}$ in these two cores are most likely attributed to enhanced lake productivity after the 1960s associated with the increased anthropogenic nitrogen input. In contrast, in core KAW14-1A, the corrected $\delta^{13} \mathrm{C}_{\mathrm{C} 16: 0}$ values were almost constant at around $-31.5 \%$ until $\sim 1988$, despite the $\delta^{15} \mathrm{~N}_{\text {bulk }}$ increases (Fig. 5b), suggesting the influence of factors other than algal productivity on these values.

Although numerous processes are known to affect the $\delta^{13} \mathrm{C}$ of aquatic biomarkers (Huang et al. 1999; Castañeda et al. 2009; Aichner et al. 2010; Kristen et al. 2010), one possible explanation for the difference in timing of the $\delta^{13} \mathrm{C}_{\mathrm{C} 16: 0}$ excursions may be related to the availability of dissolved $\mathrm{CO}_{2}$ among the basins. Lake algae usually use dissolved $\mathrm{CO}_{2}$ as a carbon source, however, under conditions of diminished dissolved $\mathrm{CO}_{2}$, they assimilate dissolved 
$\mathrm{HCO}_{3}{ }^{-}$, which has significantly larger $\delta^{13} \mathrm{C}$ values ( $\sim 8 \%$ ) compared to those of dissolved $\mathrm{CO}_{2}$ (Hollander and McKenzie 1991). Hence, the depletion in the $\delta^{13} \mathrm{C}_{\mathrm{C} 16: 0}$ values in core KAW14-1A after the 1960s (compared with the other cores) can be partly explained by the high availability of dissolved $\mathrm{CO}_{2}$ in the central basin, due to the input of a large amount of soil-derived $\mathrm{CO}_{2}$ through groundwater discharge from large alluvial fans (Fig. 1). Delivery of such an isotopically light soil DIC may have further lowered the algal $\delta^{13} \mathrm{C}$ (Meyers 2003), as suggested by the high C/N ratios from the 1960s to the 1980s (Fig. 4).

In Lake Kawaguchi, the annual mean concentrations of TN and phosphorus in the surface water gradually decreased after 2000 , following the construction of the sewage system (Nakamura et al. 2016). However, our geochemical records clearly show high algal productivity and enhanced organic matter deposition in recent decades, indicating that eutrophication remains an ongoing process. The recent improvement in lake water quality (transparency, suspended solids [SS] and TN) at the central basin is likely to be a consequence of the transfer of nutrients to the sediment by enhanced productivity, rather than a decrease in the amount of nutrient inflow into the lake. Hence, further studies are needed to better understand nutrient budget and sources in Lake Kawaguchi, to implement effective measures to reduce nutrient loading and to restore water quality.

\section{Conclusions}

In this study, we examined organic geochemical proxies, such as TOC, TN, $\delta^{15} \mathrm{~N}$ and $\delta^{13} \mathrm{C}$ of TOC, and an aquatic biomarker $\left(\mathrm{C}_{16}\right.$ fatty acid) in Lake Kawaguchi sediment to reveal anthropogenic impact on the lake environment and the accumulation of natural organic matter over the past 130 years. Major findings are summarized as follows:

1. Parallel increases in the TOC MAR and $\mathrm{C} / \mathrm{N}$ ratio in core KAW14-7A from the 1960s to the 1980s suggest an accelerated delivery of terrestrial organic matter to the lake via anthropogenic land-use changes. In contrast, the $\mathrm{C} / \mathrm{N}$ ratios in the western and central basins (KAW14-1A and KAW14-4B) were almost constant prior to the 1980s and the late 1980s, respectively, suggesting that increasing trends in the TOC MAR values in these cores were most likely due to the onset of eutrophication associated with rapid economic growth after the mid-1950s.

2. The $\delta^{15} \mathrm{~N}_{\text {bulk }}$ showed gradual increases from the late $1870 \mathrm{~s}$, providing evidence for anthropogenic nitrogen input to the lake before the apparent eutrophication. After the $1960 \mathrm{~s}-1970 \mathrm{~s}$, the $\delta^{15-}$ $\mathrm{N}_{\text {bulk }}$ began to increase rapidly, demonstrating water deterioration as a result of the direct discharge of nutrients from domestic wastewater.

3. Contemporaneous increases in $\delta^{13} \mathrm{C}_{\mathrm{C} 16: 0}$ and $\delta^{15-}$ $\mathrm{N}_{\text {bulk }}$ values in cores KAW14-4B and KAW14-7A indicate that increased input of anthropogenic nitrogen was a major cause for enhanced lake productivity after the 1960s. In contrast, the $\delta^{13} \mathrm{C}_{\mathrm{C} 16: 0}$ in core KAW14-1A did not track the $\delta^{15} \mathrm{~N}_{\text {bulk }}$ after the 1960s, suggesting the influence of factors other than algal productivity (e.g., availability of dissolved $\mathrm{CO}_{2}$ and changes in the $\delta^{13} \mathrm{C}$ of dissolved $\mathrm{CO}_{2}$ ).

4. Our geochemical records demonstrate that eutrophication remains an ongoing process, which highlights the need for additional measures to reduce nutrient loading and restore water quality in Lake Kawaguchi.

Acknowledgements This study used the samples that were obtained in the "QuackRecNankai" project, funded by the Belgian Science Policy Office (BELSPO BRAIN-be BR/121/ A2). Part of this study was supported by the cooperative research program of the Institute of Nature and Environmental Technology, Kanazawa University $<$ No. $32>$ and JSPS KAKENHI Grant Number 18K03769. We thank Prof. P.A. Meyers and an anonymous reviewer for constructive comments which improved the manuscript.

\section{References}

Aichner B, Wilkes H, Herzschuh U, Mischke S, Zhang C (2010) Biomarker and compound-specific $\delta^{13} \mathrm{C}$ evidence for changing environmental conditions and carbon limitation at Lake Koucha, eastern Tibetan Plateau. J Paleolimnol 43:873-899. https://doi.org/10.1007/s10933-009-9375-y

Buesseler K, Aoyama M, Fukasawa M (2011) Impacts of the Fukushima nuclear power plants on marine radioactivity. Environ Sci Technol 45:9931. https://doi.org/10.1021/ es202816c

Carpenter SR (1981) Submersed vegetation: an internal factor in lake ecosystem succession. Am Nat 118:372-383 
Carpenter SR, Caraco NF, Correll DL, Howarth RW, Sharpley AN, Smith VH (1998) Nonpoint pollution of surface waters with phosphorus and nitrogen. Ecol Appl 8:559-568

Castañeda IS, Schouten S (2011) A review of molecular organic proxies for examining modern and ancient lacustrine environments. Quat Sci Rev 30:2851-2891. https://doi.org/ 10.1016/j.quascirev.2011.07.009

Castañeda IS, Werne JP, Johnson TC, Powers LA (2011) Organic geochemical records from Lake Malawi (East Africa) of the last 700 years, part II : Biomarker evidence for recent changes in primary productivity. Palaeogeogr Palaeoclimatol Palaeoecol 303:140-154. https://doi.org/ 10.1016/j.palaeo.2010.01.006

Castañeda IS, Werne JP, Johnsona TC (2009) Influence of climate change on algal community structure and primary productivity of Lake Malawi (East Africa) from the Last Glacial Maximum to present. Limnol Oceanogr 54:2431-2447. https://doi.org/10.4319/lo.2009.54.6_part_ 2.2431

Chislock MF, Doster E, Zitomer RA, Wilson AE (2013) Eutrophication: Causes, consequences, and controls in aquatic ecosystems. Nat Educ Knowl 4:10

Hamajima Y, Komura K (2004) Background components of Ge detectors in Ogoya underground laboratory. Appl Radiat Isot 61:179-183. https://doi.org/10.1016/j.apradiso.2004. 03.041

Harwood JL (1996) Recent advances in the biosynthesis of plant fatty acids. Biochim Biophys Acta 1301:7-56. https://doi. org/10.1016/0005-2760(95)00242-1

Herczeg AL, Smith AK, Dighton JC (2001) A 120 year record of changes in nitrogen and carbon cycling in Lake Alexandrina, South Australia: $\mathrm{C}: \mathrm{N}, \delta^{15} \mathrm{~N}$ and $\delta^{13} \mathrm{C}$ in sediments. Appl Geochemistry 16:73-84. https://doi.org/10.1016/ S0883-2927(00)00016-0

Hirabayashi K, Oga K, Yoshizawa K, Yoshida N, Kazama F (2012) A long-term eutrophication process observed from the changes in the horizontal distribution of profundal oligochaete fauna in mesotrophic-eutrophic Lake Kawaguchi, Japan. Turkish J Zool 36:39-46. https://doi.org/10. 3906/zoo-0912-18

Hodell DA, Schelske CL (1998) Production, sedimentation, and isotopic composition of organic matter in Lake Ontario. Limnol Oceanogr 43:200-214. https://doi.org/10.4319/lo. 1998.43.2.0200

Hollander DJ, McKenzie JA (1991) $\mathrm{CO}_{2}$ control on carbonisotope fractionation during aqueous photosynthesis: a paleo- $\mathrm{pCO}_{2}$ barometer. Geology 19:929-932. https://doi. org/10.1130/0091-7613(1991)019<0929:CCOCIF $>2.3$. $\mathrm{CO} ; 2$

Hollander DJ, McKenzie JA, Lo Ten Haven H (1992) A 200 year sedimentary record of progressive eutrophication in Lake Greifen (Switzerland): implications for the origin of organic-carbon- rich sediments. Geology 20:825-828. https://doi.org/10.1130/0091-7613(1992)020<0825: AYSROP $>2.3 . \mathrm{CO} ; 2$

Hollander DJ, Smith M (2001) Microbially mediated carbon cycling as a control on the $\delta^{13} \mathrm{C}$ of sedimentary carbon in eutrophic Lake Mendota (USA): New models for interpreting isotopic excursions in the sedimentary record. Geochim Cosmochim Acta 65:4321-4337
Honda MC, Aono T, Aoyama M, Hamajima Y, Kawakami H, Kitamura M, Masumoto Y, Miyazawa Y, Takigawa M, Saino T (2012) Dispersion of artificial caesium-134 and 137 in the western North Pacific one month after the Fukushima accident. Geochem J 46:e1-e9

Horiuchi S, Lee Y, Watanabe M, Fujita E (1992) Some limnological characteristics of Mt. Fuji. Proc Inst Nat Sci Nihon Univ 27:45-56

Huang Y, Street-Perrott FA, Perrott RA, Metzger P, Eglinton G (1999) Glacial-interglacial environmental changes inferred from molecular and compound-specific $\delta^{13} \mathrm{C}$ analyses of sediments from Sacred Lake. Mt Kenya Geochim Cosmochim Acta 63:1383-1404. https://doi.org/10.1016/ S0016-7037(99)00074-5

Kobayashi H, Koshimizu S, Fukasawa R, Kyotani T, Uchiyama T, Iwatsuki M (2000) Organic chemical analysis of sediment cores from Lake Kawaguchi in Yamanashi Prefecture, Central Japan. Proc 10th Symp Geo-Environments Geo-Tecnics 217-222

Krishnaswamy S, Lal D, Martin JM, Meybeck M (1971) Geochronology of lake sediments. Earth Planet Sci Lett 11:407-411. $821 \mathrm{X}(71) 90202-0$

Kristen I, Wilkes H, Vieth A, Zink KG, Plessen B, Thorpe J, Partridge TC, Oberhänsli H (2010) Biomarker and stable carbon isotope analyses of sedimentary organic matter from Lake Tswaing: Evidence for deglacial wetness and early Holocene drought from South Africa. J Paleolimnol 44:143-160. https://doi.org/10.1007/s10933-0099393-9

Kumar A, Hage-Hassan J, Baskaran M, Miller CJ, Selegean JP, Creech CT (2016) Multiple sediment cores from reservoirs are needed to reconstruct recent watershed changes from stable isotopes $\left(\delta^{13} \mathrm{C}\right.$ and $\left.\delta^{15} \mathrm{~N}\right)$ and $\mathrm{C} / \mathrm{N}$ ratios: case studies from the mid-western United States. J Paleolimnol 56:15-31. https://doi.org/10.1007/s10933-016-9888-0

Leavitt PR, Brock CS, Ebel C, Patoine A (2006) Landscapescale effects of urban nitrogen on a chain of freshwater lakes in central North America. Limnol Oceanogr 51:2262-2277. https://doi.org/10.4319/lo.2006.51.5.2262

Lu YH, Meyers PA, Robbins JA, Eadie BJ, Hawley N, Hyeun JK (2014) Sensitivity of sediment geochemical proxies to coring location and corer type in a large lake: Implications for paleolimnological reconstruction. Geochemistry, Geophys Geosystems 15:1960-1976. https://doi.org/10.1002/ 2013GC004989.Received

Mayr C, Fey M, Haberzettl T, Janssen S, Lücke A, Maidana NI, Ohlendorf C, Schäbitz F, Schleser GH, Struck U, Wille M, Zolitschka B (2005) Palaeoenvironmental changes in southern Patagonia during the last millennium recorded in lake sediments from Laguna Azul (Argentina). Palaeogeogr Palaeoclimatol Palaeoecol 228:203-227. https://doi. org/10.1016/j.palaeo.2005.06.001

Meyers PA (2003) Applications of organic geochemistry to paleolimnological reconstructions: a summary of examples from the Laurentian Great Lakes. Org Geochem 34:261-289. https://doi.org/10.1016/s01466380(02)00168-7

Meyers PA (1994) Preservation of elemental and isotopic source identification of sedimentary organic matter. Chem Geol 
144:289-302.

2541(94)90059-0

Meyers PA, Ishiwatari R (1993) Lacustrine organic geochemistry-an overview of indicators of organic matter sources and diagenesis in lake sediments. Org Geochem 20:867-900. https://doi.org/10.1016/01466380(93)90100-P

Meyers PA, Lallier-Vergès E (1999) Lacustrine sedimentary organic matter records of Late Quaternary paleoclimates. J Paleolimnol 21:345-372. https://doi.org/10.1023/A: 1008073732192

Nakamura S, Uejima T, Watanabe H, Matsuyama-serisawa K, Serisawa Y (2016) Seasonal changes and long-term fluctuations of water quality in the Fuji Five Lakes, Central Japan (in Japanese). Mt Fuji Res 10:31-40

Ochiai S, Nagao S, Itono T, Suzuki T, Kashiwaya K, Yonebayashi K, Okazaki M, Kaeriyama M, Qin Y-X, Hasegawa T, Yamamoto M (2015) Recent eutropication and environmental changes in the catchment inferred from geochemical properties of Lake Onuma sediments in Japan. In: Kashiwaya K, Shen J, Kim JY (eds) Earth surface processes and environmental changes in East Asia. Springer, Tokyo, pp 257-268

Ogihara S, Fukushima Y, Koshimizu S (2002) Behavior of polluted organic matter in the sediments of Lake Kawaguchi. Res Org Geochemistry 17:65-69

Ritchie JC, McHenry JR (1990) Application of radioactive fallout Cesium-137 for measuring soil erosion and sediment accumulation rates and patterns: a review. J Environ Qual 19:215-233. https://doi.org/10.2134/jeq1990. 00472425001900020006x

Robbins J (1978) Geochemical and geophysical applications of radioactive lead. In: Nriagu $\mathrm{J}$ (ed) The biogeochemistry of lead in the environment. Elsevier, Amsterdam, pp 285-393

Sakaguchi A, Yamamoto M, Shimizu T, Koshimizu S (2004) Geochemical record of $U$ and $\mathrm{Th}$ isotopes in bottom sediments of Lake Kawaguchi at the foot of Mt. Fuji. Central Japan J Radioanal Nucl Chem 262:617-628. https://doi. org/10.1007/s10967-004-0484-9

Sarkar S, Wilkes H, Prasad S, Brauer A, Riedel N, Stebich M, Basavaiah N, Sachse D (2014) Spatial heterogeneity in lipid biomarker distributions in the catchment and sediments of a crater lake in central India. Org Geochem 66:125-136. https://doi.org/10.1016/j.orggeochem.2013. 11.009

Schelske CL, Hodell DA (1995) Using carbon isotopes of bulk sedimentary organic matter to reconstruct the history of nutrient loading and eutrophication in Lake Erie. Limnol Oceanogr 40:918-929

Smith VH, Tilman GD, Nekola JC (1999) Eutrophication : impacts of excess nutrient inputs on freshwater, marine, and terrestrial ecosystems. Environ Pollut 100:179-196

Talbot MR (2005) Nitrogen isotopes in palaeolimnology. Tracking environmental change using lake sediments: physical and chemical techniques. Kluwer, Dordrecht, pp 401-439

Teranes JL, Bernasconi SM (2000) The record of nitrate utilization and productivity limitation provided by $\delta^{15} \mathrm{~N}$ values in lake organic matter - a study of sediment trap and core sediments from Baldeggersee, Switzerland. Limnol Oceanogr 45:801-813. https://doi.org/10.4319/lo.2000.45. 4.0801

Umezawa Y, Hosono T, Onodera S, Siringand F, Buapeng S, Delinom R, Yoshimizu C, Tayasu I, Nagata T, Taniguchi M (2009) Tracing the sources of nitrate and ammonium concentrations in groundwater at developing Asian megacities, using GIS data and nitrate $\delta^{15} \mathrm{~N}$ and $\delta^{18} \mathrm{O}$. Sci Total Environ 407:3219-3231

Wang J, Zhu L, Nishimura M, Nakamura T, Ju J, Xie M, Takahiro W, Testsuya M (2009) Spatial variability and correlation of environmental proxies during the past 18,000 years among multiple cores from Lake Pumoyum Co, Tibet, China. J Paleolimnol 42:303-315. https://doi.org/10. 1007/s10933-008-9277-4

Yamamoto S, Miyairi Y, Yokoyama Y, Suga H, Ogawa NO, Ohkouchi N (2020) Compound-specific radiocarbon analysis of organic compounds from Mount Fuji proximal lake (Lake Kawaguchi) sediment, central Japan. Radiocarbon 62:439-451. https://doi.org/10.1017/rdc.2019.158

Yamamoto S, Uchiyama T, Miyairi Y, Yokoyama Y (2018) Volcanic and environmental influences of Mt. Fuji on the $\delta^{13} \mathrm{C}$ of terrestrially-derived n-alkanoic acids in sediment from Lake Yamanaka, central Japan. Org Geochem 119:50-58. https://doi.org/10.1016/j.orggeochem.2018.02. 002

Yamanashi Prefecture (1993) The water quality of the Fuji Five Lakes over 21 years (1971-1991) (in Japanese). Yamanashi Prefecture, Kofu

Yoshida K, Kunikita D, Miyazaki Y, Nishida Y, Miyao T, Matsuzaki H (2013) Dating and stable isotope analysis of charred residues on the incipient jomon pottery (Japan). Radiocarbon 55:1322-1333

Yoshimura S, Kawada S (1942) Limnological studies of Fuji Five Lake II: Physicochemical characteristics of water in Lakes Kawaguchi and Shoji in summer (in Japanese). Geogr Rev Jpn 7:539-559

Yoshimura S, Kawada S (1944) Limnological studies of Fuji Five Lakes III: Detail measurement of Lake Kawaguchi and water temperature gelogy (in Japanese). Geogr Rev Jpn 20:12-20

Yoshizawa K, Yamamoto T (2017) Eutrophication of Lake Kawaguchi based on diatom assemblages in the sediments. Annu Rep Yamanashi Inst Public Heal 61:53-56

Publisher's Note Springer Nature remains neutral with regard to jurisdictional claims in published maps and institutional affiliations. 